\title{
Arthur W. Hummel
}

\section{4-1975}

On March 10, 1975, Arthur W. Hummel died at the age of ninety-one at Friends House, Sandy Spring, Maryland, near Washington. This brought to a close the long career of the first president of the Association for Asian Studies (organized in 1948 as the Far Eastern Association), one of the best-known and most distinguished pioneers of Asian studies in America.

Arthur William Hummel was born in Warrenton, Missouri, on March 6, 1884. His early life was far from easy. His father died about two weeks before he and his twin brother, William Frederick, were born; and his mother died at the early age of 37 in the spring of 1897 , when the boys were only twelve years old. Arthur lived with relatives in Nashville, Illinois, for the next several years while he was in high school. During this period he worked on a farm in the summers, and kept up the reading and speaking knowledge of the German language, which he had acquired from his German-born grandparents and his mother.

On his graduation from high school in 1903, he learned that his grades had been somewhat inflated and that he was not fully prepared for university work. He and his brother were fortunate in receiving free tuition to attend the Morgan Park Academyofficially, the Academy of the University of Chicago for Boys, Morgan Park, Illinoiswhich was an excellent preparatory school. Years later, he said of the two preparatory years at the Academy that his brother and he found them "a life-enhancing experience which we can never forget." It enabled him to enter the University of Chicago in I90s without examination, and he received his bachelor's degree from that institution in 1909 . Subsequently, in 19I1 he received a Master's degree and in 1914 a Bachelor of Divinityboth from Chicago.

Space does not permit here a description of the many types of part-time employment which made it possible for him to pursue his education. It should be pointed out, however, that in each case he sought to benefit not only from the wage he earned (which was usually remarkably small), but by learning what he could from the experience itself. Thus he recalled that his service as an usher in the Leon Mandel Assembly Hall at the University of Chicago, wearing cap and gown, taught him dignity and decorum and gave him an opportunity to hear many of the leading speakers of his day. Selling stereoscopic views to Scandinavian farm families in North Dakota during the summers taught him how to approach and communicate with persons of a very different background, and how to arouse their interest in what he had to offer. He found this experience very valuable later in teaching, in public lecturing, and even in securing funds for projects he undertook in promoting Chinese studies in America.

Two important influences upon Dr. Hummel's intellectual history should be mentioned here. Looking back sixty years later, he regarded the years he had spent in the University of Chicago-in its preparatory school, in the University itself as an undergraduate, in its Graduate School, and in its Divinity School-as:

years of comparative peace and tranquility, made so perhaps by the prevailing philosophy of inevitable progress.... It then seemed that our scientific control of Nature could give us all we needed: health, physical comfort, and happiness. The 
optimism of those years had some effect on religion. Many students began to doubt the eternal verities, and the teachings of such studies as anthropology and sociology unsettled them. . . My skepticism took the form of wondering even then what a teacher would do if he actually found the truth. Would it make any difference in his personal conduct or in his home life?

It is interesting and significant that, even at this time, he was primarily concerned not with the epistemological problems of knowing, but with the effect that knowledge could have on ethical conduct and on interpersonal relations. It is understandable, therefore, that he later found the traditional Chinese concern with these issues to be profoundly congenial. His years in China reinforced these interests, which he continued to pursue throughout the remaining years of his life.

A second important intellectual influence was that of a Canadian professor at the University of Chicago named Henry Burton Sharman (Ph.D. Graduate Divinity School, University of Chicago, 1906; died 1953). He was a man of independent means, whose specialty was examination of the teachings of the first three Gospels. He wanted in his classes only undergraduates, who, he believed, would tend to be free of theological preconceptions. He never revealed his own theological views, but urged the students to examine the existing record and reach their own interpretations. Dr. Hummel, sixty years later, stressed the importance to him of "the sincerity and the uncompromising honesty of our search. It influenced my study for good in every field, including my later studies of the Chinese classics.'

It is not surprising, therefore, that after he reached China he became much interested in the work of that country's critical historians-Ts'ui Shu (1740-1816), Ku Chieh-kang (born 1893), Hu Shih (1891-1962), and others. This long-standing interest bore fruit later in his doctoral dissertation, The Autobiograpby of a Cbinese Historian, for which he received the Ph.D. degree in 1931 from the University of Leiden, the Netherlands.

Soon after receiving his Master's degree in 1911, the young Arthur Hummel began teaching history in a high school in Chattanooga, Tennessee. After some six months, he received a cable from a friend in Japan named Roy Smith (born I878), who had begun teaching there after graduating from the University of Illinois in 1902, had returned to the United States to study at the University of Chicago, and had been a contemporary of Arthur Hummel there. Since 1909 he had been teaching at the Kobe Higher Commercial School (Kōbe Kōtō Shōgyō Gakkō), later known as the Kobe University of Commerce. His cable stated that a similar position was open in the same school.

This opportunity to visit the Orient strongly appealed to young Hummel, who, during his study in the University of Chicago, had become much interested in the Student Volunteer Movement for Foreign Missions. This small but quite influential movement had been initiated in the 1890 s by John R. Mott (1865-1955) and Robert E. Speer (1867-1947). In the interests of world unity, these leaders hoped that chosen students of outstanding intelligence and character would volunteer to devote their lives to service in foreign lands as doctors, teachers, and ministers. Hummel had joined the University's Student Volunteer band with, as he said later, "the vague hope that I might one day find a career in China or Japan." He believed that accepting the position in Kobe would offer him a chance "to test myself in Asia, to find out whether I was physically and temperamentally suited to the climate, the people, and the work." He borrowed $\$ 350$ from an uncle to make the trip to Japan, where he landed in March IgI2.

Arthur Hummel served as an instructor in English in the Higher Commercial School for two years, but in the summers of both years he went to Ku-ling, Kiangsi Province, China, to visit his twin brother, who had been teaching history and religious education in 
the University of Nanking since 1908. These visits aroused Arthur Hummel's interest in the great contributions China had made to Japan, not only in its writing system, but also in its influences on philosophy, art, and literature, and in other fields as well. He also became aware of how these influences had been altered in Japan and had come to play their roles in the distinctive Japanese civilization. He decided that he wanted to study these influences more closely in the country of their origin, and that China was the country to which he was best suited.

In I9I4, at the conclusion of his two years in Japan, he returned to the United States. On October 8 of that year, he married Ruth Emily Bookwalter, whom he had met in I9II, and to whom he had become engaged by letter in 1913. In November they left for China under the auspices of the American Board of Commissioners for Foreign Missions (which in 1961 was merged with the missionary enterprises of several other Protestant denominations to form the United Church Board for World Ministries).

After a year of full-time language study in Peking, the Hummels moved to Fenchow (now Fen-yang), Shansi, where they arrived on September 19, 1915. During the next ten years, he taught English and performed various administrative duties in the Boys' Middle School that was associated with the Mission in Fenchow. In his spare time in this period, he not only continued his study of the Chinese language, but also acquired an enthusiasm for old Chinese coins (of which he collected more than 2,000 different varieties) and for old Chinese maps. Many years later he recalled how each day, after his work at the school was completed, he visited the shops in downtown Fenchow, a trading center of importance on a camel trail from Northwest China, where old coins and old maps (some dating from the Ming period, $1368-1644$ ) were for sale at extremely low prices. His coin and map collections were of great use to him, besides their interest as hobbies. The coins gave him and his wife much practice in identifying the reign periods of Chinese history; and the maps (which he studied intensively) were later to play a crucial part in the opening of his long and fruitful career in the Library of Congress.

$\mathrm{He}$ also closely observed Chinese customs, habits, and social organization, and developed an avid interest in every aspect of Chinese civilization. Much that he was seeing and learning was reflected in the proverbs of China, which became yet another enthusiasm, one in which he took great and lifelong delight. His writing and lectures were often seasoned with these apt sayings, of which he had a large collection.

In connection with his continuing study of the Chinese language, he read a number of local histories (fang-chib) of Fenchow and the surrounding regions. The knowledge he acquired in this way concerning the history, geography, customs, and beliefs of the area gave him many excellent subjects for conversation with persons living there. Made aware of his interest through these conversations, many of his Chinese friends brought him for examination old books, maps, coins, specimens of calligraphy, and art objects, thus helping him gain much information that otherwise would not have come to him. This interest in Chinese local histories continued after his appointment to the Library of Congress staff, and he zealously sought works of this type for addition to the Library's collections.

In a conversation on August 20, 1971, he referred to the ten years he had spent in the interior of China as "the most interesting, and most important, years of my life." Though this was clearly his recollection of the interesting and rewarding years he had spent in Fenchow, the most important from the standpoint of Asian studies in America were doubtless his twenty-seven years in the Library of Congress, for which his years in China served as a preparation.

In 1924 the Hummels moved to Peking, where for three years he lectured on Chinese 
history and civilization to Western students in the institution then called the Yenching School of Chinese Studies (later known as the College of Chinese Studies). This continued until 1927, when, as a result of the turmoil brought about by the Northern Expedition for the unification of China, it was necessary for the Hummels and other foreigners to leave.

Not long after his return to the United States, he was invited to deliver a talk on China and Chinese civilization at a meeting of the Institute of Politics, which was being conducted on the campus of Williams College in Williamstown, Massachusetts, during July and August 1927. There he met Colonel Lawrence Martin (1880-1955), then Chief of the Division of Maps (now the Geography and Map Division) of the Library of Congress. He told Colonel Martin of his efforts to collect old Chinese maps during his fourteen years of residence in Fenchow and Peking. Subsequently, Colonel Martin wrote to him and invited him to bring the maps to Washington, where they could be examined in detail. Shortly thereafter, Arthur Hummel brought to Washington a steamer trunk full of maps, including those dating from the Ming period, but none later than about 1850. Colonel Martin also invited Dr. Herbert Putnam (I86I-I955), then Librarian of Congress, to examine the maps and to hear Arthur Hummel's discussion of them. At the end of the presentation, Dr. Putnam asked Hummel to leave the maps for further study, and then astonished him by inviting him to join the Library of Congress staff and build up the collections relating to China, Japan, and other countries of Asia.

After discussion with his wife, Hummel agreed to come on a temporary basis for a period of six to eight months, since he expected to return to China the following year. But conditions in China did not improve; therefore, in 1928, he accepted a permanent appointment as Chief of a newly established Division of Chinese Literature. This was the first permanent appointment in the Library for a specialist on Asia, though the Library prior to this time had received a considerable number of Asian works (totaling some 100,000 volumes) through the efforts of Dr. Walter T. Swingle (1871-1952) of the Bureau of Plant Industry, U. S. Department of Agriculture, and Professor Kan-ichi Asakawa (1873-1948) of Yale University, as well as through various gifts. By the time Dr. Hummel retired in 1954, the Division had expanded to five Sections (Chinese and Korean, Japanese, Southern Asia, Near East, and Hebraic); its name had been changed to the Orientalia Division; and its holdings of materials in Asian languages totaled more than 797,000 volumes, of which over 291,000 were in the Chinese language.

The maps he had brought to Washington for examination and had left on deposit in the Library of Congress, together with three more which he added in 1929; were purchased in 1930 by Andrew W. Mellon of Pittsburgh, Pennsylvania, as a gift for the Library. These 38 early maps and atlases, most of which are in manuscript, constitute the nucleus of the Hummel Collection of Rare Chinese Cartography in the custody of the Library's Geography and Map Division. An additional collection of 3 I colored maps and atlases was acquired for the Library by Dr. Hummel in 1934, when he was visiting China on a procurement trip. Still another group of rare manuscript maps was presented to the Library by Dr. Hummel in 196I, some seven years after his retirement from active service.

Beginning with the Report of the Librarian of Congress for the Fiscal Year Ending June 30, 1928, and continuing through the report for fiscal 1940, each annual report contained an extensive essay by Dr. Hummel, describing, often in considerable depth, the significant new Chinese works acquired by the Library during the past year. These acquisitions were discussed in relation to works already held by the Library, and their 
importance in the history of Chinese civilization was made clear. Certain of the maps and atlases just mentioned were described in these essays. Each year these sections of the annual report were distributed by the Library as offprints. They were widely read by students of China, both in the United States and abroad; after the annual reports ceased carrying this type of information, the Library continued to receive requests for these offprints. Beginning in fiscal 1944, the Library resumed acquisitions reports in a new publication entitled the Library of Congress Quarterly Journal of Current Acquisitions (LCQJCA). This Journal had begun publication in 1943 as a supplement to the Librarian's annual report, which in 1941 had become chiefly a document of administration. Dr. Hummel's acquisitions essays, both in the annual reports and in the Journal, have been reprinted in the three volumes entitled Chinese Collections in the Library of Congress, compiled by P. K. Yu and published in 1974 by the Center for Chinese Research Materials, Association of Research Libraries, Washington, D. C.

Early during his service in the Library, Dr. Hummel was appointed Chairman of the Committee for the Promotion of Chinese Studies of the American Council of Learned Societies. He held this post from 1930 to 1934. During these years he worked closely with Mortimer Graves (born 1893), who was at that time Administrative Secretary, subsequently Executive Director, and finally President of the ACLS. Mr. Graves frequently attended the Librarian's Round Table, luncheon meetings presided over for many years by Dr. Putnam, which brought together Division Chiefs of the Library and guests who were not members of the Library staff but who were prominent in various fields of study. Years later Dr. Hummel looked back on his attendance at the Round Table, which was abolished after Dr. Putnam's retirement, as one of the most stimulating experiences of his Library career. During these years, Mr. Graves and Dr. Hummel developed a lifelong and - from the standpoint of Asian studies-extremely productive friendship. Mr. Graves, in cooperation with Dr. Hummel and several other colleagues, began (apparently in 1931, though the first issue is undated; the second issue is dated November 20, 1931) a mimeographed "List of Articles on Chinese Subjects." Beginning as an eight-page annotated list of periodical articles, this publication continued until 1935. It was superseded by the Bulletin of Far Eastern Bibliography, compiled by Earl H. Pritchard, which was published by the ACLS during the years 19361940. This was followed in turn by the bibliographical sections of the Far Eastern Quarterly; and these have ultimately developed into the annual Bibliography of Asian Studies, a major publication of the Association for Asian Studies.

Working together, Mr. Graves and Dr. Hummel conceived the plan for a biographical dictionary of the Ch'ing period. The purpose was first of all to produce a much-needed reference tool, which would make it no longer necessary for students of China to duplicate one another's efforts in looking up the same facts. A second purpose was to give training in Chinese sources to young and promising students of China. Four fellowships supported by funds from the Rockefeller Foundation were awarded by the ACLS to make this possible. The undertaking began in 1934; the two resulting volumes were published in 1943 and 1944 by the U.S. Government Printing Office under the title Eminent Chinese of the Ching Period, 1644-1912. Most enthusiastically received by students of China both in the United States and abroad, this work went through several printings at the GPO, and was subsequently reprinted ( 2 vols. in one) in 1964 by the Paragon Book Gallery, Ltd. in New York and in 1970 by the Ch'eng Wen Publishing Company in Taipei.

It is significant to note that 22 years later, in the "Bibliographical Suggestions" 
appended to East Asia, the Modern Transformation, by Professors Fairbank, Reischauer, and Craig (Houghton Mifflin Co., Boston, 1965), Eminent Chinese is referred to as still "the one indispensable work" for the Ch "ing period. It has also served as a model for the four-volume Biograpbical Dictionary of Republican China compiled by Howard L. Boorman and Richard C. Howard (Columbia University Press, New York, 1967-71) and for the Ming biographical dictionary compiled by Professor L. Carrington Goodrich and Fang Chao-ying, scheduled for publication in late 1975 by the Columbia University Press.

Anyone who worked at all closely with Dr. Hummel soon became aware of his great and continuing concern with proper and appropriate forms of expression, and with the necessity for stating ideas with absolute precision and clarity. He often referred to the work done on Basic English by C. K. Ogden and I. A. Richards, and stated that the ideas of these men had exerted great influence on his style of writing. He by no means limited his vocabulary, which was very large, but he did devote extraordinary effort to finding the right word. As one who worked with him on Eminent Cbinese (it is my recollection that we read the entire second volume aloud), I was impressed by the great number of times he halted, searched for a word, tried several alternatives, and finally selected a new word or recast the entire sentence. He was equally critical of the writings of others, and was very quick to recognize prolixity or pomposity.

During the 1930s, in addition to his many duties at the Library of Congress, Dr. Hummel was active in a series of summer seminars sponsored by the ACLS, for the purpose of arousing interest in and improving instruction relating to East Asia, and in particular to China. He served as Director of such seminars at Harvard University in 1932, at the University of California (Berkeley) in 1934, and again at Berkeley in 1937. He served as a special lecturer in the seminars given at Columbia University in 1935 (where he had already taught one day a week for two years-1930-32-while Professor L. Carrington Goodrich was on leave), at the University of Michigan in 1939, and at the University of Colorado in 1940. The Librarian of Congress, Dr. Putnam, was in no way critical of these extended absences; rather, he commended these efforts, stating that by this teaching Dr. Hummel was "interpreting the collections," and making them better known to students who would later want to use them.

While teaching part-time at Columbia University in 1930-32, Arthur Hummel again met the celebrated Dutch scholar Professor J.J.L. Duyvendak, whom he had known in China, and who was now also teaching at Columbia. Professor Duyvendak became aware that Hummel had for some years been interested in the movement among Chinese schol. ars for the critical re-evaluation of their own history, and that he was personally well acquainted with some of the leading figures in that movement; he had, in fact, carefully studied the first volume of Ku Chieh-kang's Ku shib pien (Symposium on Ancient Chi. nese History) when it was published in 1926, and had reviewed it in The China Journal in November of that year. Professor Duyvendak therefore encouraged Hummel to prepare a dissertation on this subject for submission to the University of Leiden. This work, The Autobiograpby of a Chinese Historian, was essentially a translation of the autobiographical preface to the $K u$ shib pien, with an extensive background introduction and notes. It was published in 1931 as the first volume in the new Sinica Leidensia series. In preparing it, Hummel worked closely with Professor Duyvendak, who checked the translation, sentence by sentence, against the original text, and contributed many useful suggestions. A pioneer work, which revealed to Western students what Chinese scholars were doing in the re-examination of their own history, this dissertation is still widely used and frequently cited. It was reprinted in 1966 by Paragon in New York, and has also been reprinted by Ch'eng Wen in Taipei. 
During the war years, Dr. Hummel put his gift for communication to work through lectures on China. He also contributed a number of suggestions and Chinese sayings to the Army's Pocket Guide to China. One of the most notable of his wartime activities was a special broadcast in Chinese commemorating the birthday of Confucius, which was transmitted to China on August 27, 1944.

Dr. Hummel continued to keep abreast of Asian affairs in lectures after the war. There is no doubt that he enjoyed opening new vistas of thought both to members of general audiences and to students in his classes. After his retirement in 1954, in September 1956-at the age of seventy-he undertook to serve as Adjunct Professor in the College of Arts and Sciences at American University in Washington, and continued his teaching there until April 1963 . During these years he offered a considerable array of courses, including "Philosophies of the East," "History of China since the Ming Dynasty," "Philosophy and Religion," "Comparative Religion," "Chinese Civilization," and "Christian Belief." In 1963 and again in 1966 he served as Professorial Lecturer in History at George Washington University (more than three decades earlier, in 1930, he had served that university as Lecturer on the Far East). At the Memorial Service held at the Friends' Meeting House in Washington on March 14, 1975, his son Arthur W. Hummel, Jr., Ambassador of the United States to Ethiopia, stated that he thought his father would want to be remembered as a teacher; that he had enjoyed teaching, both inside and outside of the classroom; and that he may well have considered it to be in the long run his most important contribution.

Dr. Hummel's continuing close association with the ACLS, together with continuing assistance from the Rockefeller Foundation, made it possible for him to bring to the United States a number of Chinese scholars who worked in the Orientalia Division for varying periods of time. Among them were Chu Shih-chia, compiler of $A$ Catalog of Local Histories in the Library of Congress (U.S. Government Printing Office, 1942); Wang Chung-min, compiler of the two-volume work $A$ Descriptive Catalog of Rare Chinese Books in the Library of Congress (the manuscript was completed in 1943, but the work was not published by the Government Printing Office until 1957); Dr. S. Y. Teng, who wrote for Eminent Chinese of the Ch'ing Period the biographical accounts of leaders on both sides of the Taiping Rebellion, 1850 to 1864 ; and Dr. K. T. Wu, who joined the Library in 1938 and remained an active member of the staff until his retirement in 1975. During the decade (1934 to 1944) when Eminent Cbinese was being prepared, Dr. Hummel's chief assistant was Mr. Fang Chao-ying, who, as Dr. Hummel stated in his Editor's Note to that work, "produced for these volumes more sketches than any other single contributor. Mrs. Fang, who signs her contributions with her maiden name Tu Lien-che, rendered a like service by her loyalty to the enterprise and her conscientious attention to many vexing details."

Indeed, Dr. Hummel's continuing association with Chinese scholars and writers was one of the most pleasant and rewarding aspects of his career. His friendship with Dr. Hu Shih, whom he met in Peking in 1924 , continued throughout Dr. Hu's life. Hummel also maintained long-standing personal friendships with Professor Chiang Monlin (1886-1964), Professor P. W. Kuo (1880-1969), and many others. A special mention should be made of his long and productive friendship with Dr. T.L. Yuan (1895-I965), Associate Director of the National Library of Peiping from 1929 to 1942, and Director of that Library until 1949. T. L. Yuan had spent three summers in the Library of Congress during the 1920s, while a student in Columbia University. After his return to China he continued to help the Library in many ways, both through assisting in acquisitions work and through recommending persons who came to the Library for special projects. In 1949 
he joined the Library of Congress staff as Consultant in Chinese Literature; in this capacity he edited Wang Chung-min's manuscript for $A$ Descriptive Catalog of Rare Chinese Books in the Library of Congress. He later served as a regular member of the Library's staff (1957 to 1965).

Another major accomplishment of Dr. Hummel's administration was the microfilming of over 2,800 rare works belonging to the National Library of Peiping. These works, which had been moved to South China shortly before the occupation of North China by Japanese forces in 1937, and which were sent to the United States for safekeeping during the Second World War, reached the Library only one month before the outbreak at Pearl Harbor. In return for protecting them, the Library was granted permission to microfilm them and to make positive copies of the films available for purchase by other libraries. The only condition stated by Dr. Hu Shih, then Chinese Ambassador to the United States, was that three complete sets of the films should be made available to libraries in China; the Library of Congress fulfilled this condition.

The microfilming operation, which required nearly four years of continuous effort, was supervised by Wang Chung-min, the well-known Chinese bibliographer previously mentioned, who selected the items to be filmed, examined them carefully, and prepared descriptive notices on them. More than 2,500,000 pages were filmed in this operation. In each case, the completed film was checked page by page against the original work, to make sure that no pages had been omitted in the filming process. Complete sets of the films have been acquired by libraries throughout the world. Owing to unsettled conditions in China after the war, the original works were not returned immediately after the end of hostilities. Subsequently a request for them was received from the Chinese Government, and they were sent to Taipei, where they are now in the custody of the $\mathrm{Na}$ tional Central Library. In 1969 that Library published a catalog of these rare books under the title Kuo-li Pei-p'ing t'u-sbu-kuan shan-pen sbu-mu, which not only serves as an author, title, and classified index to the contents of the films, but includes also the relatively small number of items that were not microfilmed while they were in Washington.

Dr. Hummel held a Guggenheim Fellowship for three years, 1953 to I956. During these years, along with other projects, he continued his work, begun almost a decade earlier, of annotating for publication the journal of Harriet Low of Salem, Massachusetts, which chronicles her visit to Macao and Canton in the years 1829 to 1834 . The work is complete, and awaits a publisher.

Besides being the first president of the Association for Asian Studies, he was also a member of the American Oriental Society (president in 1940), the American Philosophical Society, the Royal Asiatic Society, the Cosmos Club, the Literary Society of Washington, the Friends of Buddhism, Inc. (patron), and the Sino-American Cultural Society of Washington (first president). Beginning in 1957, he played an active role in the establishment of the Association of Teachers of Chinese Language and Culture in American Colleges and Universities. In 1929 he and Mrs. Hummel (who died on July 17, 1967, at the age of 79) had joined the Society of Friends. During his last few years he lectured to that Society on "Religions of the World" and other topics, as well as giving many highly valued impromptu discourses at Sunday meetings.

All those who knew him were aware of his gentle and compassionate nature. His judgments of institutions and actions were often penetrating but always kind. It happens that one of the writers of this notice, many months before Dr. Hummel's death, had occasion to compare various translations of the Confucian Analects. He was astonished by 
the number of times when characterizations of the "superior man" accurately described Dr. Hummel, his aims, his ideals, and, in particular, his relationships with other persons. Perhaps his favorite concept was jen, which he translated as "human-heartedness." Truly, he was a chün-tzu.

Wasbington, D.C.

Edwin G. Beal and Janet F. Beal

\section{BIBLIOGRAPHY OF PUBLICATIONS}

Since Dr. Hummel's essays on important new Chinese acquisitions of the Library of Congress (1928 through 1953) have all been reprinted in Chinese Collections in the Library of Congress (Washington, 1974), specific references to the individual reports have been omitted from this Bibliography in order to conserve space.

1920 "The Pu Tzu-hsia Tradition in Shansi." New China Review, v. 2, no. 5, Oct 1920: 440-447.

1925 "The Case against Force in Chinese Philosophy." Chinese Social and Political Science Review, v. 9, no. 2, Apr 1925: 334-350.

1926 "Force in Chinese Philosophy." World Tomorrow, v. 9, no. I, Jan 1926: 15-17.

"Some Thoughts on the Literary Revolution." The New Mandarin, v. I, no. 3, June 1926: 8-I2.

Review of Ku Chieh-kang, Ku shib pien (Discussions in Ancient Chinese History), Vol. I. The China Journal of Science and Arts, v. 5, no. 5, Nov 1926: 248-249.

1928 Wang Kuo-wei, "Chinese Foot-Measures of the Past Nineteen Centuries," translated by Arthur W. Hummel and Fung Yu-lan. Journal of the North China Branch of the Royal Asiatic Society, v. 59, 1928: [111]-123.

1929

"What Chinese Historians Are Doing in Their Own History." American Historical Review (hereafter listed as $A H R$ ), v. 34, no. 4, July 1929: 715-724.

Review of Owen Lattimore, The Desert Road to Turkestan. The China Journal, v. II, no. 4, Oct 1929: 181.

1930 "The New-Culture Movement in China." American Academy of Political and Social Science. Annals, v. 152, Nov 1930: 55-62.

1931 The Autobiograpby of a Chinese Historian [Ku Chieh-kang], Being the Preface to a Symposium on Ancient Chinese History ( $K u$ shib pien), translated and annotated by Arthur W. Hummel. Leyden, E. J. Brill, 1931, [v]-xliii, 199, [r] p. (Sinica leidensia edidit Institutum sinologicum Lugduno-Batavum, I.)

"Report of the Committee on the Promotion of Chinese Studies [for 1930]." American Council of Learned Societies (hereafter listed as ACLS). Bulletin, no. 15, May 1931: $55-56$.

"Ts' ung shu." Journal of the American Oriental Society, v. 5I, no. I, Mar 1931: 40-46.

1932 "Committee on the Promotion of Chinese Studies; Report of Activities, 1931." ACLS Bulletin, no. 18, Oct 1932: 65-66.

"Transcription of Chinese Names." The Library Journal, v. 57, no. 21, I Dec 1932: 1006-1007.

1933 "The Administration of a Chinese Library in the West." In ACLS Devoted to Humanistic Studies; Committee for the Promotion of Chinese Studies. Careers for Students of Chinese Language and Civilization, edited by Lewis Hodous. Chicago, published for the American Council, Institure of Pacific Relations, 1933. p. 42-48.

"Committee on the Promotion of Chinese Studies; Report of Activities, 1932." ACLS Bulletin, no. 20, Dec 1933: 72-73. 
1934 Review, with comment by Nathaniel Peffer, of All Men Are Brothers (Shui bu cbuan), translated by Pearl S. Buck. Asia, v. 34, no. I, Jan 1934: 22-25.

Review of Carrol Brown Malone, History of the Peking Summer Palaces Under the Ch'ing Dynasty. Pacific Historical Review, v. 3, no. 4, Dec 1934: 458-459.

Review of 1.A. Richards, Basic Rules of Reason. Pacific Affairs, v. 7, no. 4, Dec 1934: 484-486.

1936 U. S. Library of Congress. Orientalia Division. Some Eminent Chinese of the Seventeenth Century; Twenty-two Biographies from a Proposed Dictionary of Cb'ing Dynasty Biography. Edited by Arthur W. Hummel. Baltimore, Md., Waverly Press, I936. vi, $21 \mathrm{p}$.

"Berthold Laufer, 1874-1943." American Antbropologist, new (2d) series, v. 38, no. I, Jan-Mar 1936: IOI-III.

Includes bibliography prepared by Dr. Paul S. Martin.

"Chinese, Japanese, and Other East Asiatic Books in the Library of Congress." Amerasia, v. I, no. 9, Nov 1937: 410-414.

"Committees on Far Eastern Studies; Report of Activities, 1936. Compiled by the Permanent Secretary [Waldo G. Leland] with the assistance of the Chairmen A. W. Hummel (Committee on Chinese Studies) and Langdon Warner (Committee on Japanese Studies)." ACLS Bulletin, no. 26, June 1937: 58-66.

"Correspondence Concerning William C. Hunter." With Phillip de Vargas. Yenching Journal of Social Studies, v. 2, no. 2, Feb 1940: 294-296.

"The Development of the Book in China." Journal of the American Oriental Society, v. 6I, no. 2, June 194I: 71-76.

"The Printed Herbal of 1249 A.D." Isis, v. 33, pt. 4, Dec I94I: 439-442.

"Some American Pioneers in Chinese Studies." Notes on Far Eastern Studies in America, no. 9, June 1941: $1-6$.

1942 "China and the Democratic Way." American Scholar, v. II, no. 2, Apr 1942: 190-200.

"Toward Understanding China." The Booklist, v. 38, no. 8, I Jan 1942: 147-149, 158.

I943 U.S. Library of Congress. Orientalia Division. Eminent Chinese of the Ch'ing Period (1644-1912). Vol. I, A-O. Edited by Arthur W. Hummel. Washington, D. C., Government Printing Office, 1943. xi, 604 p.

"The Rockhill Exhibit." Far Eastern Survey, v. 12, no. 7, 5 Apr 1943: 72.

U.S. Library of Congress. Orientalia Division. Eminent Chinese of the Ch'ing Period (1644-1912). Vol. II, P-Z. Edited by Arthur W. Hummel. Washington, D. C., Government Printing Office, 1944. p. 605-I103. (Volumes paged continuously.)

"Carl Whiting Bishop, 1881-1942." ACLS Bulletin, no. 36, Dec 1944: 44-45.

"Movable Type Printing in China." U.S. Library of Congress. Quarterly Journal of Current Acquisitions (hereafter listed as LCQJCA), v. I, no. 2, Oct-Dec 1943 [published in 1944]: 18-24.

"Posters and News Bulletins in Wartime China." LCQJCA, v. I, no. 2, Oct-Dec 1943 [published in 1944]: 58-59.

Review of Owen and Elinor Lattimore, The Making of Modern China. AHR, v. 50, no. I, Oct 1944: 126-127.

"The Journal of Harriet Low." LCQJCA, v. 2, no. 3-4, Jan-June 1945: 45-60.

1946 "An Ancient Chinese Manuscript." LCQJCA, v. 3, no. 4, Aug 1946: 6. Describes the Chinese version of the Mabäparinirväna, chüan 1-2, donated by $\mathrm{Hu}$ Shih.

1947 "Books on Korean Law." LCQJCA, v. 4, no. 4, Aug I947: 7-8.

Review of Chiang Monlin, Tides from the West: A Cbinese Autobiograpby. Far Eastern Survey, v. 16, no. I0, 21 May 1947: 120.

Review of The Suma Oriental of Tomé Pires: An Account of the East, from the Red Sea to Japan, Written in Malacca and India in 1512-1515, and The Book of Francisco Rodrigues Rutter of a Voyage in the Red Sea, Nautical Rules, Almanak and Maps, 
Written and Drawn in the East before 1515, translated and edited by Armando Cortesão. $A H R$, v. 52, no. 2, Jan 1947: 382.

Review of Leonardo Olschki, Guillaume Boucher: A French Artist at the Court of the Khan. $A H R$, v. 52, no. 2, Jan 1947: 360.

"Portrait of a Scholar." In There Is Another China. New York, King's Crown Press, Columbia University, 1948, p. 131-150.

Review of H. G. Creel, Confucius, the Man and the Myth. AHR, v. 55, no. I, Oct 1949: 145.

Review of Fung Yu-lan, A Short History of Chinese Philosopby, edited by Derk Bodde. $A H R$, v. 54, no. 3, Apr 1949: 686-687.

$1950^{2}$ Review of John King Fairbank and Kwang-ching Liu, Modern China: A Bibliographical Guide to Chinese Works, 1898-1937. AHR, v. 55, no. 4, July 1950: 986-987.

Review of G. B. Sansom, The Western World and Japan: $A$ Study of the Interaction of European and Asiatic Cultures. New York Herald'Tribune, Book Section, 12 Feb 1950.

"Some Basic Principles in Chinese Culture." American Philosophical Society. Proceedings, v. 95, no. 4, 17 Aug 1951: 453-456.

Review of Hope Danby, The Garden of Perfect Brightness: The History of the Yüan Ming Yüan and of the Emperor Who Lived There. $A H R$, v. 56, no. 2, Jan 1951: 404-405.

"Note on Death of Walter T. Swingle." U. S. Library of Congress. Information Bulletin, v. 1I, no. 4 21 Jan 1952: 17-18.

Review of George N. Kates, The Years That Were Fat. Far Eastern Quarterly (hereafter listed as $F E Q)$, v. I2, no. I, Nov 1952: 85-86.

Review of Rene Grousset, The Rise and Splendour of the Chinese Empire. FEQ, v. 13, no. I, Nov 1953: 86-88.

Review of Francis L. K. Hsu, Americans and Chinese: Two Ways of Life. AHR, v. 59, no. 1, Oct 1953: 175.

"Ancient Archival Depository in Peking." American Archivist, v. 17, no. 4, Oct 1954: 317-318.

Translation of article by T. L. Yuan on the Huang shih ch' eng in T'u-sbu-kuan bsüeh chi.k'an, v. 2, no. 3, Sept 1928.

"Chinese Culture." In Understanding Other Cultures, edited by William A. Parker. Washington, ACLS, 1954, p. 55-63.

"The Growth of the Orientalia Collections." LCQJCA, v. II, no. 2, Feb 1954: 69-87.

Review of Hsiao-tung Fei, China's Gentry: Essays in Rural-Urban Relations. FEQ, v. 13, no. 3, May 1954: 333-334.

Review of Joseph R. Levenson, Liang Cb'i-ch'ao and the Mind of Modern China. FEQ, v. 13, no. I, Nov 1954: IIO-112.

1955 Review of Han Yü-shan, Elements of Chinese Historiograpby. AHR, v. 60, no. 4, July 1955: $975-976$.

Review of Joseph Needham, Science and Civilization in China: Vol. I, Introductory Orientations. $A H R$, v. 60, no. 3, Apr 1955: G10-612.

Review of Joseph Needham, Science and Civilization in Cbina: Vol. I, Introductory Orientations. $F E Q$, v. 14, no. 4, Aug 1955: 559-560.

Review of Edwin O. Reischauer, Ennin's Diary: The Record of a Pilgrimage to China in Search of the Law and Ennin's Travels in T'ang China. Harvard Journal of Asiatic Studies, v. 18, no. 3/4, Dec 1955: 467-474.

Review of A. C. Moule, Quinsai, with Other Notes on Marco Polo. AHR, v. 63, no. I, Oct 1957: 176 .

1958 Review of Burton Watson, Ssu-ma Cb'ien, Grand Historian of China. AHR, v. 63, no. 4 , July 1958: 992. 
1959 "China's Place in Humanistic Studies." Chinese Culture, v. 2, no. 3, Dec 1959: 23-30. Review of Albert Feuerwerker, China's Early Industrialization: Sheng Hsuan-buai (1844-1916) and Mandarin Enterprise. AHR, v. 64, no. 4, July 1959: 964-965.

1960 "The Art of Social Relations in China." Philosophy East and West, v. 10, no. 1-2 (combined issue), Apr-July 1960: 13-22.

Review of Joseph Needham and Wang Ling, Science and Civilization in China: Vol. III, Matbematics and the Sciences of the Heavens and the Earth. AHR, v. 65, no. 3, Apr 1960: 614-616.

Review of Confucianism in Action, edited by David S. Nivison and Arthur F. Wright. $A H R$, v. 65, no. 4, July 1960: 616-617.

"A High Peak in Mahāyāna Buddhism."

A talk delivered I2 Mar 1960, to the Washington Friends of Buddhism. Reproduced for private distribution.

I9GI Review of Biography of Lü Kuang, translated and annotated by Richard B. Mather. $A H R$, v. 66, no. 3, Apr I96r: 809-810.

1963 Review of An Embassy to China: Being the Journal Kept by Lord Macartney during bis Embassy to the Emperor Ch'ien-lung, 1793-1794, edited with notes by J. L. Cram. mer-Byng. $A H R$, v. 68 , no. 4, July 1963: 1114.

Review of Joseph Needham et al., Science and Civilization in China: Vol. IV, Physics and Pbysical Technology; Part I, Physics. AHR, v. 68, no. 2, Jan 1963: 463-464.

Review of Tsuen-hsuin Tsien, Written on Bamboo and Silk: The Beginnings of Chinese Books and Inscriptions. $A H R$, v. 68, no. 3, Apr 1963: 812-813.

1964 Review of Mencius, translated and annotated by W.A.C.H. Dobson. Journal of Asian Studies, v. 23, no. 3, May 1964: 463-464. 